\title{
Semi-detailed survey of soils of Ceará's semiarid region: Lavoura Seca Experimental Farm ${ }^{1}$
}

\author{
Levantamento semidetalhado de solos do semiárido cearense: Fazenda Experimental \\ Lavoura Seca
}

\author{
Ryshardson Geovane Pereira de Oliveira e Silva ${ }^{2 *}$, Jaedson Cláudio Anunciato Mota ${ }^{3}$ and Raul Shiso Toma ${ }^{3}$
}

\begin{abstract}
The semiarid region of northeastern Brazil has more than 53 million inhabitants who depend, directly or indirectly, on the resources that the region offers. Among these resources, the soil is highlighted as one of the most important. Due to the importance attributed to the knowledge on the pedological and morphological characteristics of the soils of the Brazilian northeastern semiarid region, the aim of this study was to identify and characterize the different soil classes on the Lavoura Seca Experimental Farm, in the municipality of Quixadá, Ceará, Brazil, through the traditional method of soil mapping. The selected site is located in the municipality of Quixadá, Ceará, with a total extension of approximately 190 hectares. A regular grid of $200 \mathrm{~m}$ x $200 \mathrm{~m}$ was established to determine the sampling sites, totaling 47 collection points. The soil samples were collected with an auger at depths of 0-20, 40-60 and 80-100 cm, and the chemical and granulometric analyses were then carried out to select the pit opening sites and classify the units according to the Brazilian Soil Classification System (SIBCS). The predominant soil classes in the study area were: Neossolos Litólicos Eutróficos típicos (59.4\%), Planossolos Háplicos Eutróficos típicos (20.4\%), Argissolos Vermelhos Eutróficos típicos and abrúpticos (15.9\%) and Luvissolos Crômicos Órticos típicos $(4.3 \%)$. Differences in parent material, relief and climate were the main influencing factors for the occurrence of a diversity of soil classes in the studied area, which shows large extensions of young and shallow soils, as well as evolved and deep soils.
\end{abstract}

Key words: Soil map. Conventional mapping. Northeastern Brazil.

RESUMO - A região semiárida do nordeste brasileiro possui mais de 53 milhões de habitantes que dependem, direta ou indiretamente, dos recursos que a região oferece. Dentre esses recursos, o solo é destacado como um dos mais importantes. Em função da importância atribuída ao conhecimento das características pedológicas e morfológicas dos solos do semiárido do nordeste brasileiro, o presente estudo teve como objetivo identificar e caracterizar as diferentes classes de solo existentes na Fazenda Experimental Lavoura Seca, no município de Quixadá, Ceará, por meio do método tradicional de mapeamento de solos. O local selecionado localiza-se no município cearense de Quixadá, com uma extensão total de aproximadamente 190 hectares. Foi estabelecida uma grade regular de $200 \mathrm{~m}$ x $200 \mathrm{~m}$ para determinação dos locais de amostragem, totalizando 47 pontos de coleta. As amostras de solo foram coletadas com trado nas profundidades 0-20, 40-60 e 80-100 cm, procedendo-se, posteriormente, as análises químicas e granulométricas para seleção dos locais de abertura das trincheiras e classificação das unidades taxonômicas segundo o Sistema Brasileiro de Classificação de Solos (SIBCS). As classes de solos predominantes na área de estudos foram: Neossolos Litólicos Eutróficos típicos (60\%), Planossolos Háplicos Eutróficos típicos (20\%), Argissolos Vermelhos Eutróficos típicos e abrúpticos (16\%) e Luvissolos Crômicos Órticos típicos (4\%). As diferenças no material de origem, no relevo e no clima foram os principais fatores influenciadores para a ocorrência de uma diversidade de classes de solo na área estudada, apresentando grandes extensões de solos jovens e rasos, bem como solos evoluídos e profundos.

Palavras-chave: Mapa de solos. Mapeamento convencional. Nordeste do Brasil.

DOI: $10.5935 / 1806-6690.20200028$

*Author for correspondence

Received for publication on 15/08/2019; approved on 11/12/2019

${ }^{1}$ Trabalho extraído da Dissertação do primeiro autor apresentada ao Programa de Pós-Graduação em Ciência do Solo, Universidade Federal do Ceará/ UFC

${ }^{2}$ Programa de Pós-Graduação em Ciência do Solo, Departamento de Ciências do Solo, Universidade Federal do Ceará/UFC, Campus do Pici, FortalezaCE, Brasil, rgeovane@outlook.com.br (ORCID ID 0000-0002-2200-3013)

32Departamento de Ciências do Solo, Universidade Federal do Ceará/UFC, Campus do Pici, Fortaleza-CE, Brasil, jaedson.mota@ ufc.br (ORCID ID 0000-0002-1261-9754), raulstoma@ufc.br (ORCID ID 0000-0001-5585-6832) 


\section{INTRODUCTION}

The semiarid climate is characterized by low rainfall, low relative humidity and high potential for evaporation (ALVARES et al., 2014). Brazil has a semiarid climate territory that occupies $1,128,697 \mathrm{~km}^{2}$, which corresponds to approximately $12 \%$ of its area total, encompassing 1,262 municipalities, distributed in the nine states of the Northeast region and in the State of Minas Gerais (BRASIL, 2018).

The semiarid region of northeastern Brazil is the most densely populated in the world (MARENGO, 2008; MARENGO; TORRES; ALVES, 2016), with more than 53 million inhabitants who depend, directly or indirectly, on this environment. Recurrent and long-lasting droughts in the region create situations of water deficit that compromise agricultural activities, posing risks to food security for residents (EAKIN; LEMOS; NELSON, 2014). In addition, the advance of desertification combined with the intensive use of soil favors the exhaustion of environmental resources, giving this region a high vulnerability (INTERGOVERNMENTAL PANEL ON CLIMATE CHANGE, 2014).

It is increasingly evident the importance of soil and its role in nature, being necessary for the proper functioning of ecosystems, as well as to guarantee the planet's food and environmental security (TEN CATEN et al., 2012), since it acts from the compartmentalization and regulation of water flow and nutrient cycling to the promotion of support to plants. In this context, the use of pedological surveys and soil mapping is indispensable to obtain information related to the soils existing in a given area of interest because knowing the properties of soils and their distribution is fundamental for their correct use, management and conservation (DALMOLIN et al., 2004), as well as to improve the economic return with its exploitation (GIASSON; INDA JUNIOR; NASCIMENTO, 2006).

One of the most consolidated ways to conduct a survey and/or mapping of soils is through the method usually called traditional, in which the pedologist makes inferences according to the observations of the interaction between the variables that determine the formation of the soil (DOKUCHAEV, 1879). Traditional soil mapping begins with a technique called photointerpretation, in which the pedologist uses his experience and professional knowledge to delimit homogeneous polygons in an image of the area to be studied, thus establishing a relationship between the soil and the environment in which it is located and deducing which types of soils are associated with that polygon, which is later confirmed or not with the prospection of samples in the field and analysis in the laboratory (FRANCO et al., 2015).
The soil map, produced after the survey, can be considered an indispensable tool for the planning of use and management of natural resources, because the information contained in it assists the government in proposing territorial policies and constructing legal and administrative instruments directed to the formulation of guidelines and legislation aimed at the development, combined with environmental conservation and preservation (CARVALHO; NUNES; ANTUNES, 2013).

Given the importance of the knowledge on the pedological and morphological characteristics of the soils of the semiarid region of northeastern Brazil, with a view to giving them correct use and management, the present study aimed to identify and characterize the different types of soil existing on the Lavoura Seca Experimental Farm, in the municipality of Quixadá, Ceará, Brazil, through the traditional method of soil mapping.

\section{MATERIAL AND METHODS}

\section{Characterization of the study area}

The site selected for this study is located in the municipality of Quixadá, $168 \mathrm{~km}$ away from Fortaleza, in the Sertão de Quixeramobim mesoregion, between the municipalities of Itapiúna, Choró and Ibaretama. The area, with approximately 190 hectares, corresponds to one of the experimental farms belonging to the Federal University of Ceará (UFC), between the geographical coordinates $5^{\circ} 00^{\prime} 10^{\prime \prime}$ to $5^{\circ} 01^{\prime} 29^{\prime \prime}$ South latitude and $38^{\circ} 59^{\prime} 50^{\prime \prime}$ to 38 59'34" West longitude (Figure 1).

The climate of the region is BSwh type (hot and semiarid) according to Köppen's climate classification (ALVARES et al., 2014), with two climatic seasons prevailing throughout the year, a rainy one between February and June and a dry one between July and January. The predominant vegetation is hypoxerophilic Caatinga and the formation of the relief is gently undulating, composed of several rock formations called inselbergs or monoliths, with gneiss substrate. Lithology is represented by rocks of the northeastern complex, corresponding to Sertaneja depressions, residual massifs and inselbergs.

\section{Methodological procedures}

Prior to the beginning of the prospections, a regular grid of $200 \mathrm{~m}$ x $200 \mathrm{~m}$ was established to determine the sampling sites, totaling 47 collection points. Soil samples were collected with a Dutch auger at depths of 0-20, 40-60 and $80-100 \mathrm{~cm}$, aiming at identifying and establishing the limits of the mapping units (SANTOS et al., 1995). 
Figure 1 - Location of the Lavoura Seca Farm - UFC

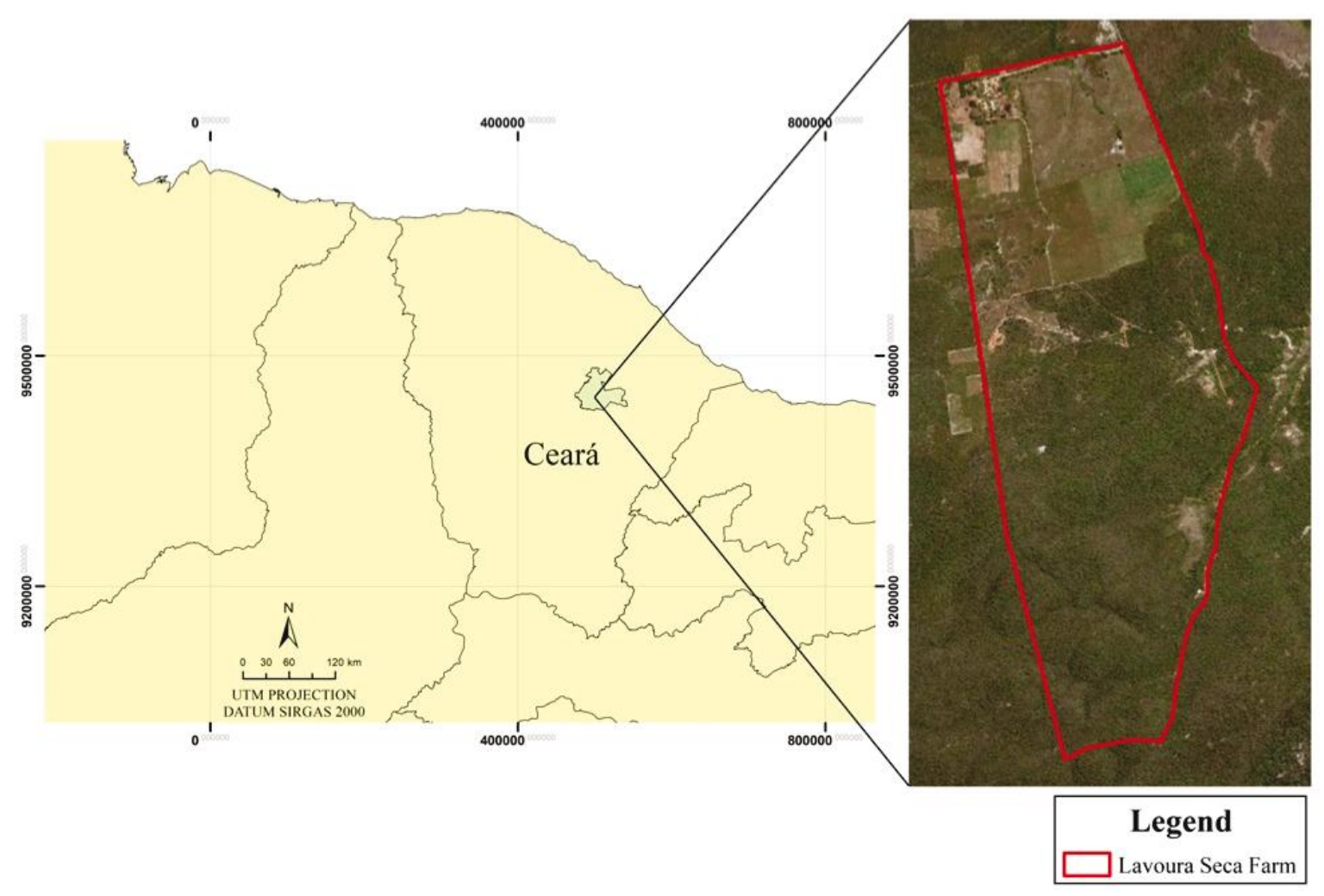

All samples collected were subjected to chemical and particle-size analyses for subsequent classification of the taxonomic units according to the Brazilian Soil Classification System (SIBCS) (SANTOS et al., 2018). Particle-size analysis was performed by sedimentation of solids in liquid medium, using the pipette method (CAMARGO et al., 2009). Regarding chemical analyses, the following parameters were determined: $\mathrm{pH}\left(\mathrm{H}_{2} \mathrm{O}\right.$, $0.01 \mathrm{~mol} \mathrm{~L}^{-1} \mathrm{CaCl}_{2}$ solution and $1 \mathrm{~mol} \mathrm{~L}^{-1} \mathrm{KCl}$ solution), $\mathrm{P}, \mathrm{Na}, \mathrm{K}^{+}, \mathrm{Al}^{3+}, \mathrm{H}+\mathrm{Al}, \mathrm{EC}, \mathrm{CEC}$ and $\mathrm{V} \%$ (EMPRESA BRASILEIRA DE PESQUISA AGROPECUÁRIA, 2009), OC (MENDONÇA; MATOS, 2005), $\mathrm{N}$ total, $\mathrm{Ca}^{2+}$ and $\mathrm{Mg}^{2+}$ (RAIJ et al., 2001).

To assist in the delimitation of the mapping units, a contour map of the farm was elaborated, and contour curves were also drawn from SRTM (Shuttle Radar Topography Mission) data of $30 \mathrm{~m}$ (Figure 2). Thus, with the first results of soil analyses, the contour map, field observations and other data of the region, the possible mapping units were delimited, and the sites for pit opening and complete classification of the taxonomic units were established.

As a complement, six representative profiles were subsequently described in pits (SANTOS et al., 2018), and new physical and chemical analyses were performed in the soil samples from the horizons, using
Figure 2 - Contour map of Lavoura Seca Farm - UFC

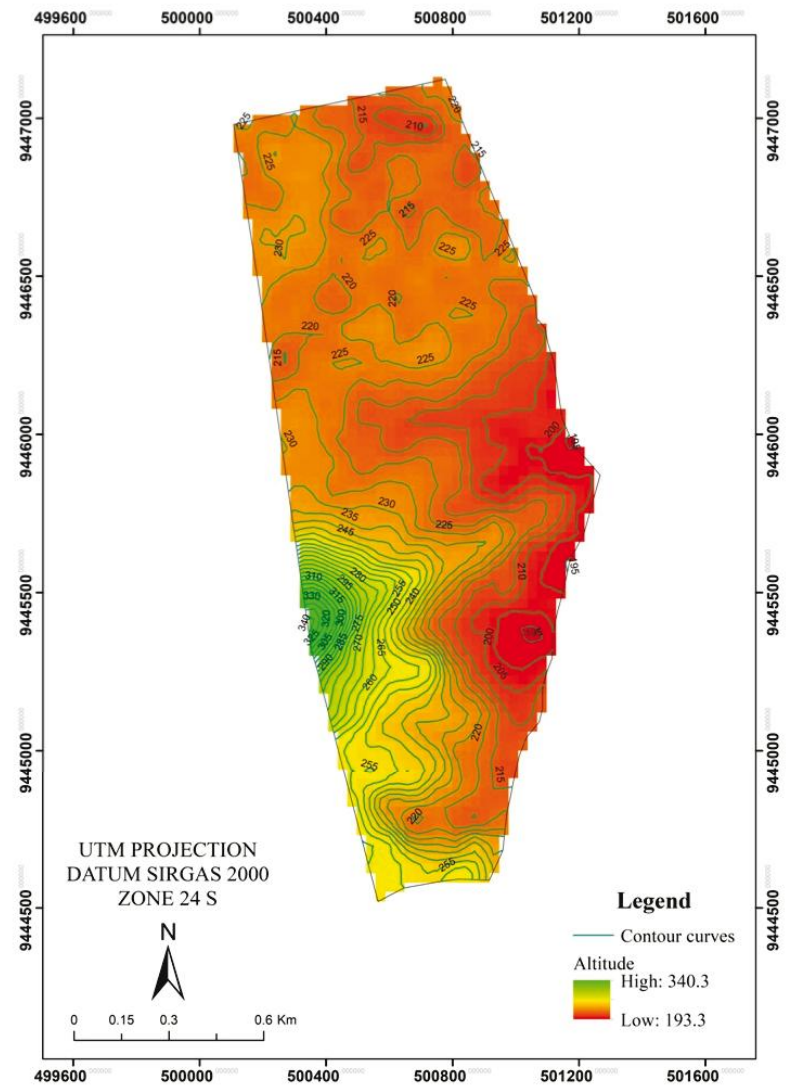


the above-mentioned methods in order to confirm the soil classes existing on the farm.

After obtaining the data regarding auger sampling points and profiles with the classification of the taxonomic units up to the fourth categorical level according to the Brazilian Soil Classification System (SANTOS et al., 2018), the limits of the polygons delineated for each of the units were defined, which enabled the construction of the semi-detailed map by the traditional method.

\section{RESULTS AND DISCUSSION}

\section{Characterization of soil samples from the sampling points}

The 47 sampling points were divided into four distinct groups according to their physical, chemical and morphological characteristics, corresponding to four soil classes of SIBCS (SANTOS et al., 2018) and, therefore, defining the mapping units present on the farm. After evaluating the characteristics of the soil samples collected and establishing a correlation with the SIBCS soil classes, 23 samples were attributed to Neossolos Litólicos, ten to Planossolos, nine to Luvissolos and five to Argissolos.

Most of the points belonging to the class of Neossolos Litólicos were located exactly where the highest element of the relief of the mapped area is located, with little variation in both the texture and the color of the samples in subsurface, which is indicative of the existence of a diagnostic horizon. As a complement, it was also observed that most points reached only the surface depth of collection or, at most, the second depth, reaching the matrix rock around 30 to $40 \mathrm{~cm}$.

The samples corresponding to the class of Planossolos were found on flat to gently undulating relief, exhibiting a grayish color, which is a common characteristic in this soil class. They also showed compaction in the deeper layers of collection, hampering the prospection several times, in addition to an abrupt textural change or, at least, a textural gradient in subsurface, indicating clay migration from the surface to the subsurface horizon.

Soil samples collected at the sampling points relative to the class of Luvissolos exhibited reddish color and texture ranging from medium to clayey, with increased clay content in subsurface. The chemical analysis indicated that most samples of this class had high-activity clay and high base saturation, characteristics that corroborate the veracity of the association established between the analyzed samples and the class to which they were attributed.
In regard to the sampling points relative to the class of Argissolos, it can be said that they had characteristics very similar to those of the samples of the class of Luvissolos, and the differentiation between them was mainly made by observing the values of clay activity and base saturation, since the samples of both classes had reddish colors, textural gradient and texture ranging from medium to clayey. It is worth highlighting that the distinction between these two classes was later confirmed through the physical and chemical characterization and the complete morphological description of the soil profiles.

\section{Characterization of soil samples from the complete profiles}

The predominant soil classes in the study area, established according to SIBCS (SANTOS et al., 2018) up to the fourth categorical level, were: Neossolos Litólicos Eutróficos típicos - RLe, Planossolos Háplicos Eutróficos típicos - SXe, Luvissolos Crômicos Órticos típicos - TCo and Argissolos Vermelhos, the latter being subdivided into Argissolos Vermelhos Eutróficos típicos - PVe1 and Argissolos Vermelhos Eutróficos abrúpticos - PVe2. It was also observed the inclusion of Plintossolos Argilúvicos Distróficos abrúpticos - FTd and Luvissolos Crômicos Órticos típicos - TCo2 in the mapping units corresponding to Planossolos and Argissolos, respectively.

In general, the soils of the Ceará's central Sertão territory are shallow to intermediately deep, with high levels of rocky outcrops and superficial stoniness, and associations of Planossolos, Luvissolos, Vertissolos, Neossolos and Argissolos are commonly found (BRASIL, 2010), attributes repeatedly observed in the soils present in this study. The results of the particle-size analysis and chemical analysis of the soil profiles described in this study are presented in Table 1 .

By observing the results of chemical and particlesize analyses related to the soil profiles, it was observed that most of the samples were included in the medium textural class $(55 \%)$, followed by the sandy textural class $(42 \%)$ and by the clayey textural class $(3 \%)$. The average clay content in the diagnostic horizons was approximately $222 \mathrm{~g} \mathrm{~kg}^{-1}$, with mostly high clay activity (average: $42 \mathrm{cmol}_{\mathrm{c}} \mathrm{kg}^{-1}$ ) and also high base saturation (average: $75 \%)$. Regarding acidity, the samples were considered moderately acidic, according to the average $\mathrm{pH}\left(\mathrm{H}_{2} \mathrm{O}\right)$ values (average: 6.4).

The soil profile referring to the RLe unit had total depth of $48 \mathrm{~cm}$, with only one A horizon subdivided into three and lithic contact just below. The soil was classified in the sandy textural class, with average sand content of $815 \mathrm{~g} \mathrm{~kg}^{-1}$ and average clay content of only $65 \mathrm{~g} \mathrm{~kg}^{-1}$. Base saturation was high (average: 79\%), with low acidity, observed through the average $\mathrm{pH} \mathrm{H}_{2} \mathrm{O}$ values (average: 6.6). 
Table 1 - Attributes analyzed in the soil samples from complete profiles

\begin{tabular}{|c|c|c|c|c|c|c|c|c|c|c|c|c|c|c|c|c|}
\hline \multirow{3}{*}{ Horiz. } & Depth & & rticle si & & $\mathrm{K}^{+}$ & $\mathrm{Na}^{2+}$ & $\mathrm{Ca}^{2+}$ & $\mathrm{Mg}^{2+}$ & $\mathrm{H}+\mathrm{Al}$ & SB & $\mathrm{T}$ & $\mathrm{V}$ & $\mathrm{C}$ & & $\mathrm{pH}$ & \\
\hline & \multirow{2}{*}{$\mathrm{cm}$} & \multicolumn{3}{|c|}{------- $\mathrm{g} \mathrm{kg}^{-1}$------- } & \multirow{2}{*}{\multicolumn{4}{|c|}{ 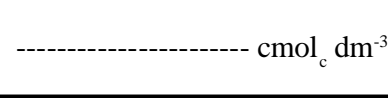 }} & & & & \multirow{2}{*}{\multicolumn{2}{|c|}{$\begin{array}{c}\% \\
---- \\
\end{array}$}} & \multirow{2}{*}{$\mathrm{H}_{2} \mathrm{O}$} & \multirow{2}{*}{$\mathrm{CaCl}_{2}$} & \multirow{2}{*}{$\mathrm{KCl}$} \\
\hline & & Sand & Clay & Silt & & & & & & & & & & & & \\
\hline \multicolumn{17}{|c|}{ NEOSSOLOS LITÓLICOS Eutróficos típicos - RLe } \\
\hline A1 & $0-22$ & 826 & 50 & 124 & 0.45 & 0.07 & 4.00 & 2.02 & 1.32 & 6.5 & 7.9 & 83 & 0.8 & 6.50 & 5.80 & 5.76 \\
\hline A2 & $22-34$ & 802 & 71 & 127 & 0.16 & 0.14 & 5.60 & 0.46 & 1.82 & 6.3 & 8.2 & 78 & 0.3 & 6.60 & 5.55 & 4.53 \\
\hline A3 & $34-48$ & 816 & 74 & 110 & 0.11 & 0.15 & 6.25 & 0.23 & 1.98 & 6.7 & 8.7 & 77 & 0.3 & 6.61 & 5.56 & 4.35 \\
\hline \multicolumn{17}{|c|}{ PLANOSSOLOS HÁPLICOS Eutróficos típicos - SXe } \\
\hline A & $0-5$ & 908 & 10 & 82 & 0.51 & 0.06 & 3.86 & 1.06 & 0.83 & 5.5 & 6.3 & 87 & 1.3 & 7.00 & 6.60 & 6.43 \\
\hline BA & $5-17$ & 896 & 28 & 76 & 0.25 & 0.06 & 2.45 & 0.80 & 1.32 & 3.5 & 4.9 & 73 & 0.6 & 6.51 & 5.75 & 5.46 \\
\hline B1t & $17-29$ & 861 & 50 & 89 & 0.25 & 0.07 & 2.11 & 0.83 & 0.66 & 3.3 & 3.9 & 83 & 0.3 & 6.70 & 5.94 & 5.43 \\
\hline $\mathrm{B} 2 \mathrm{t}$ & $29-45$ & 892 & 52 & 56 & 0.25 & 0.06 & 1.78 & 0.76 & 0.66 & 2.8 & 3.5 & 81 & 0.4 & 6.68 & 5.93 & 5.30 \\
\hline $\mathrm{BC}$ & $45-90+$ & 885 & 60 & 55 & 0.20 & 0.06 & 1.68 & 0.65 & 0.33 & 2.6 & 2.9 & 89 & 0.1 & 6.72 & 6.02 & 5.37 \\
\hline \multicolumn{17}{|c|}{ LUVISSOLOS CRÔMICOS Órticos típicos - TCo } \\
\hline A & $0-10$ & 807 & 68 & 125 & 0.50 & 0.26 & 5.42 & 0.54 & 3.14 & 6.7 & 9.9 & 68 & 2.9 & 6.54 & 6.01 & 5.83 \\
\hline $\mathrm{AB}$ & $10-20$ & 626 & 213 & 161 & 0.26 & 1.45 & 2.90 & 0.71 & 1.32 & 5.3 & 6.6 & 80 & 0.7 & 6.95 & 5.91 & 4.84 \\
\hline BA & $20-50$ & 601 & 253 & 146 & 0.17 & 1.71 & 2.60 & 0.92 & 1.16 & 5.4 & 6.6 & 82 & 0.8 & 6.58 & 5.64 & 4.50 \\
\hline $\mathrm{Bt}$ & $50-80+$ & 485 & 294 & 221 & 0.11 & 17.05 & 1.54 & 1.60 & 0.66 & 20.3 & 21.0 & 97 & 0.5 & 5.96 & 5.90 & 5.33 \\
\hline $\mathrm{C}$ & $0-10$ & 672 & 168 & 160 & 0.17 & 11.62 & 0.74 & 0 & 0 & 12.5 & 12.5 & 100 & 0.2 & 7.30 & 6.95 & 6.46 \\
\hline \multicolumn{17}{|c|}{ ARGISSOLOS VERMELHOS Eutróficos típicos - PVe1 } \\
\hline A & $0-10$ & 835 & 93 & 72 & 0.57 & 0.06 & 2.57 & 0.66 & 1.82 & 3.9 & 5.7 & 68 & 0.6 & 6.60 & 5.92 & 5.90 \\
\hline $\mathrm{AB}$ & $10-23$ & 729 & 142 & 129 & 0.36 & 0.06 & 2.27 & 0.69 & 0.83 & 3.4 & 4.2 & 80 & 0.4 & 6.90 & 6.22 & 6.08 \\
\hline BA & $23-33$ & 703 & 223 & 74 & 0.48 & 0.05 & 2.26 & 0.76 & 0.83 & 3.6 & 4.4 & 81 & 0.5 & 7.05 & 6.30 & 6.00 \\
\hline B1t & $33-48$ & 620 & 294 & 86 & 0.67 & 0.07 & 2.22 & 0.85 & 0.99 & 3.8 & 4.8 & 79 & 0.4 & 7.01 & 6.35 & 5.91 \\
\hline $\mathrm{B} 2 \mathrm{t}$ & $48-68$ & 672 & 176 & 152 & 0.67 & 0.07 & 2.22 & 0.94 & 0.66 & 3.9 & 4.6 & 86 & 0.4 & 7.30 & 6.45 & 6.24 \\
\hline B $3 t$ & $68-83$ & 653 & 208 & 139 & 0.74 & 0.07 & 2.21 & 1.03 & 0.66 & 4.1 & 4.7 & 86 & 0.5 & 7.31 & 6.58 & 6.34 \\
\hline $\mathrm{BC} 1$ & 83-108 & 764 & 130 & 106 & 1.30 & 0.12 & 3.14 & 1.38 & 0.50 & 5.9 & 6.4 & 92 & 0.3 & 7.00 & 6.56 & 6.49 \\
\hline $\mathrm{BC} 2$ & $108-123+$ & 785 & 95 & 120 & 1.07 & 0.13 & 2.39 & 1.17 & 0.83 & 4.8 & 5.6 & 85 & 0.2 & 7.30 & 6.78 & 6.48 \\
\hline \multicolumn{17}{|c|}{ ARGISSOLOS VERMELHOS Eutróficos abrúpticos - PVe2 } \\
\hline A1 & $0-17$ & 804 & 102 & 94 & 0.36 & 0.05 & 1.39 & 0.55 & 2.64 & 2.4 & 5.0 & 47 & 0.5 & 5.95 & 5.23 & 4.61 \\
\hline $\mathrm{A} 2$ & $17-29$ & 820 & 74 & 106 & 0.20 & 0.13 & 2.08 & 0.87 & 2.31 & 3.3 & 5.6 & 59 & 0.7 & 6.08 & 5.37 & 4.98 \\
\hline BA & $29-34$ & 670 & 226 & 104 & 0.31 & 0.15 & 2.52 & 1.40 & 2.97 & 4.4 & 7.4 & 60 & 0.6 & 5.31 & 4.85 & 4.32 \\
\hline B1t & $34-64$ & 551 & 354 & 95 & 0.52 & 0.12 & 2.51 & 1.41 & 3.47 & 4.6 & 8.0 & 57 & 0.6 & 5.04 & 4.55 & 4.03 \\
\hline $\mathrm{B} 2 \mathrm{t}$ & $64-111$ & 505 & 340 & 155 & 0.09 & 0.12 & 2.33 & 2.13 & 3.30 & 4.7 & 8.0 & 59 & 0.5 & 5.12 & 4.35 & 3.84 \\
\hline B3t & $111-126$ & 534 & 291 & 175 & 0.08 & 0.15 & 1.96 & 2.20 & 3.47 & 4.4 & 7.8 & 56 & 0.6 & 5.20 & 4.29 & 3.79 \\
\hline $\mathrm{BC}$ & $126-161+$ & 576 & 231 & 193 & 0.09 & 0.20 & 1.66 & 1.84 & 4.46 & 3.8 & 8.2 & 46 & 0.4 & 5.33 & 4.15 & 3.73 \\
\hline \multicolumn{17}{|c|}{ PLINTOSSOLOS ARGILÚVICOS Distróficos abrúpticos - FTd } \\
\hline $\mathrm{A}$ & $0-10$ & 829 & 57 & 114 & 0.34 & 0.07 & 2.95 & 0.95 & 1.32 & 4.3 & 5.6 & 77 & 0.9 & 6.54 & 5.95 & 6.01 \\
\hline $\mathrm{AB}$ & $10-20$ & 796 & 124 & 80 & 0.45 & 0.06 & 1.80 & 1.01 & 1.32 & 3.3 & 4.6 & 72 & 0.5 & 6.67 & 5.96 & 5.67 \\
\hline $\mathrm{Bt}$ & $20-35+$ & 547 & 343 & 110 & 0.24 & 0.07 & 1.87 & 0.89 & 3.30 & 3.1 & 6.4 & 48 & 0.5 & 5.90 & 4.94 & 4.38 \\
\hline \multicolumn{17}{|c|}{ LUVISSOLOS CRÔMICOS Órticos típicos - TCo2 } \\
\hline A & $0-2$ & 845 & 49 & 106 & 0.10 & 0.04 & 3.30 & 1.60 & 0.60 & 5.0 & 5.6 & 89 & - & 5.67 & - & - \\
\hline $\mathrm{AB}$ & $2-11$ & 776 & 97 & 127 & 0.14 & 0.04 & 1.60 & 1.10 & 2.10 & 2.9 & 5.0 & 58 & - & 5.46 & - & - \\
\hline B1t & $11-17$ & 707 & 156 & 137 & 0.14 & 0.05 & 1.80 & 1.20 & 1.20 & 3.2 & 4.4 & 73 & - & 5.90 & - & - \\
\hline $\mathrm{B} 2 \mathrm{t}$ & $17-72$ & 497 & 261 & 242 & 0.10 & 0.19 & 3.50 & 1.60 & 0.80 & 5.4 & 6.2 & 87 & - & 5.90 & - & - \\
\hline
\end{tabular}


The characterization of the profile corresponding to the SXe unit showed total soil depth greater than 90 $\mathrm{cm}$, divided into five horizons. The Planic B diagnostic horizon had thickness of $28 \mathrm{~cm}$, subdivided into two. The soil was classified in the sandy textural class, although it almost had medium texture according to its particle-size fractions, with increased clay in subsurface. Clay activity was high (average: $106.4 \mathrm{cmol} \mathrm{kg}^{-1}$ ), with base saturation also high (average: $83 \%$ ), and low acidity, observed by the average $\mathrm{pH} \mathrm{H}_{2} \mathrm{O}$ values (average: 6.7).

The profile referring to the TCo mapping unit showed a total depth of more than $170 \mathrm{~cm}$, with $55-\mathrm{cm}$ thick Bt diagnostic horizon. Its characterization classified the soil in the medium textural class, with high averages of clay activity $\left(50 \mathrm{cmol}_{\mathrm{c}} \mathrm{kg}^{-1}\right)$ and base saturation (average: $86 \%$ ). Acidity was considered weak, according to the average $\mathrm{pH} \mathrm{H}_{2} \mathrm{O}$ (average: 6.7).

Regarding the PVe mapping unit, it was observed that the profile PVe1 had a total depth of more than $120 \mathrm{~cm}$, with a 50-cm-thick Bt diagnostic horizon, while the profile referring to PVe2 had depth greater than $160 \mathrm{~cm}$, with 92$\mathrm{cm}$-thick Bt diagnostic horizon. The soil PVe 1 was classified in the medium textural class, with low clay activity (21.1 $\mathrm{cmol}_{\mathrm{c}} \mathrm{kg}^{-1}$ ) and high base saturation (average: $82 \%$ ), being considered neutral (average: 7) according to the average $\mathrm{pH} \mathrm{H}_{2} \mathrm{O}$. The soil PVe2 followed the pattern of PVe1, being classified in the same textural class, with low clay activity (26.4 $\mathrm{cmol}_{\mathrm{c}} \mathrm{kg}^{-1}$ ) and high base saturation (average: 55\%), having intermediate acidity (average $\mathrm{pH} \mathrm{H}_{2} \mathrm{O}: 5$ ).

Regarding the inclusion of FTd in the SXe mapping unit, the characterization of the profile indicated total soil depth greater than $35 \mathrm{~cm}$, divided into three horizons. The analysis of soil samples showed predominance of the medium textural class, with low clay activity $\left(18.6 \mathrm{cmol}_{\mathrm{c}} \mathrm{kg}^{-1}\right)$. Base saturation in general was high (average: 65\%) with reduction in subsurface. Acidity was moderate according to the $\mathrm{pH}_{2} \mathrm{O}$ values (average: 6.4), also with a reduction in subsurface.

The inclusion of $\mathrm{TCo} 2$ in the area of Argissolos indicated, by the characterization of the profile, total soil depth greater than $80 \mathrm{~cm}$, divided into four horizons. The diagnostic horizon, $B$ textural, had a total thickness of more than $60 \mathrm{~cm}$, being found already in the range of $20 \mathrm{~cm}$ from the soil surface. The analysis of soil samples indicated the predominance of the medium textural class, with high clay activity $\left(34.4 \mathrm{cmol}_{\mathrm{c}} \mathrm{kg}^{-1}\right)$ and high base saturation (average: 77\%). Acidity was intermediate according to the $\mathrm{pH} \mathrm{H}_{2} \mathrm{O}$ values (average: 5.7), with reduction in subsurface.

The soil map of Lavoura Seca Farm, obtained after the classification of the described soils and their complete morphological description, is presented in Figure 3.
Figure 3 - Map of soils of the Lavoura Seca Farm - UFC, obtained by the traditional mapping method

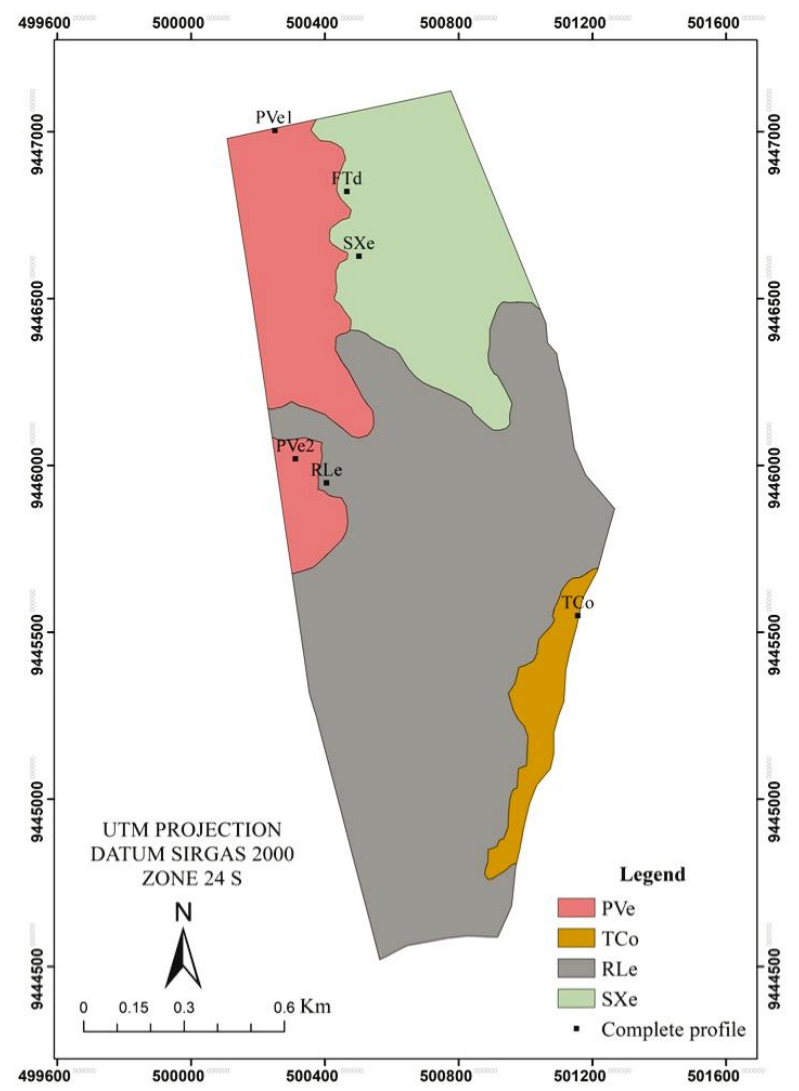

After observing the soil map constructed by the traditional mapping method and establishing a relationship with the contour map of the farm, the variability among the soil classes found in the relief slope direction becomes accentuated, changing from the highest point to the lowest point, that is, from east to west in the maps. This fact is related to the formation of the soil, demonstrating the variability of soils existing at the different points of the relief, ranging from the shallower and poorly developed soil at the top, where the factors and processes of formation act with lower intensity, to the lowest part, where the processes and factors of formation are more active, resulting in deeper soils and greater degree of development.

The division established close to half of the mapped area, indicating the distinction between mapping units RLe, PVe and SXe can also be attributed to the different existing parent materials, observed in the field, in the pit opening stage and complete description of the soil profiles, being of possibly Gneissic origin for Neossolos and Planossolos and sedimentary origin for Argissolos and Luvissolos. 


\section{Characterization of the Mapping Units}

The mapping unit comprising the Neossolos Litólicos Eutróficos típicos (RLe) occupies an area of 112.6 ha on the farm, which represents $60 \%$ of the total mapped area. This class of soils usually has low pedogenetic development (SANTOS et al., 2018), which was found in the sites where the prospections were carried out, because the depth of collection did not reach more than $40 \mathrm{~cm}$, resulting in points with only one depth of collection in the sampling phase $(0-20 \mathrm{~cm})$.

Another mitigating factor, which several times hampered the auger sampling process in georeferenced sites and the choice of the site to open the pit for classification, was the occurrence of several rocky outcrops of the Gneiss type in most of the land. Neossolos Litólicos occur in the entire semiarid region (CUNHA et al., 2010), usually in areas of strongly undulating relief, having high level of rockiness and/or stoniness and shallow depth, which constitute the main limitations of this soil class for the practice of agriculture that is not for subsistence.

As for the use and occupation, most of the area where the soil class RLe prevails is occupied by native forest, with a tree-shrub vegetation of the hyperxerophilic Caatinga type, characteristic of the predominant Caatinga biome in the region. Extensive livestock in Caatinga, with goats and, less usually, with cattle, is practiced in this mapping unit.

The mapping unit that constitutes the Planossolos Háplicos Eutróficos típicos (SXe) occupied a total of 38.7 ha, representing $20 \%$ of the total mapped area. This area showed inclusions of Plintossolos Argilúvicos Eutróficos abrúpticos (FTd), possibly originated by the segregation of iron at higher points of the relief, which was mobilized, being transported by the action of water and subsequently deposited in the area of the Planossolos, where, combined with the low permeability of the Planic B horizon and with the elevated water table, promoted the formation of mottled spots and, in a more advanced stage, plinthite.

The SXe mapping unit revealed the occurrence of gneiss rock outcrops at some points on the terrain, which also made auger sampling difficult in some georeferenced sites. As for its use and occupation, the area in which this class of soil prevails is reserved for agriculture and goat and cattle livestock; one third of the area cultivated with corn and sorghum and the other two thirds with pasture, where the herd consumes fresh during the rainy season, while this vegetation is used to make silage, in order to feed the animals in the drought period.

Regarding the inclusions of FTd, it was observed that the plinthic diagnostic horizon appeared combined with the Planic B horizon, since both soil classes are present in this mapping unit, making their distinction according to SIBCS (SANTOS et al., 2018), because Plintossolos found do not have sodic character and occur from $40 \mathrm{~cm}$ from the surface.

The mapping unit that constitutes the Luvissolos Crômicos Órticos típicos (TCo) occupied a total of 8.1 ha, making up $4 \%$ of the total mapped. In the sampling phase, some points did not reach more than $60 \mathrm{~cm}$ deep, resulting in only two depths collected (0-20 and 40-60 cm). In addition, at some collection points, the occurrence of rock outcrops was observed, related to the proximity to the RLe unit.

Regarding the use and occupation of the TCo mapping unit, agriculture is not practiced in its site of predominance, which is covered by hyperxerophilic vegetation, similar to what occurs in the unit of Neossolos Litólicos. In this unit, extensive livestock in the Caatinga is also practiced, with goats and cattle.

Close to the site of opening and description of the profile of the Luvissolos, it was possible to observe the occurrence of an erosive process in advanced stage of development, possibly caused by the joint action of factors such as the very clayey texture of the Bt horizon and the presence of more sandy overlying horizons in this soil class, which makes the soil very susceptible to erosion, and worsening factors may occur when these soils are located in sloping areas, when the $\mathrm{Bt}$ horizon remains close to the surface and in regions with high rainfall levels in a short period of time, as occurs in the northeastern semiarid region (OLIVEIRA, 2011).

The mapping unit that constitutes the Argissolos Vermelhos (PVe) occupied a total of 30.2 ha, representing $16 \%$ of the total mapped area. This unit was subdivided into Argissolos Vermelhos Eutróficos típicos (PVe1) and Argissolos Vermelhos Eutróficos abrúpticos (PVe2), with inclusions of Luvissolos Crômicos Órticos típicos (TCo) in the PVe1 mapping unit.

As for the use and occupation of the PVe mapping unit, in areas where this soil class prevails there is wide use, in both agriculture, with the cultivation of corn and sorghum, and for goat and cattle livestock farming, being also used for construction, since the headquarters of the farm, together with the places of storage and maintenance of agricultural implements, is located in this mapping unit.

\section{CONCLUSIONS}

1. The differences in the parent material, relief and climate are the main factors contributing to the occurrence of a diversity of soil classes in the studied area, being 
corroborated both by the presence in large extensions of young and shallow soils, as well as by the existence of evolved and deep soils;

2. The soil class of Neossolos Litólicos was the most present in relation to the total area occupied on the farm, followed in extension by the classes of Planossolos Háplicos, Argissolos Vermelhos and Luvissolos;

3. The soil classes found in this work of mapping are widely present in the semiarid region of Brazil, so it is extremely important to characterize it and report its chemical, physical and morphological characteristics, in order to know its potentialities and limitations.

\section{ACKNOWLEDGMENTS}

The authors thank the Coordination for the Improvement of Higher Education Personnel (CAPES) for granting the scholarship to the first author and the financial support to this research through the Graduate Support Program (PROAP).

\section{REFERENCES}

ALVARES, C. A. et al. Köppen's climate classification map for Brazil. Meteorologische Zeitschrift, v. 22, n. 6, p. 711-728, 2014.

BRASIL. Ministério da Integração Nacional. Nova delimitação semiárido. Brasília, DF, 2018. Disponível em: http://www. sudene.gov.br/images/arquivos/semiarido/arquivos/Relação_ de_Municípios_Semiárido.pdf. Acesso em: 20 jun. 2019.

BRASIL. Ministério do Desenvolvimento Agrário. Plano territorial de desenvolvimento rural e sustentável: território sertão central. Fortaleza: Instituto Agropolos do Ceará, 2010.

CAMARGO, O. A. et al. Métodos de análise química, mineralógica e física de solos do Instituto Agronômico de Campinas. Campinas: Instituto Agronômico de Campinas, 2009. Disponível em: http://www.iac.sp.gov.br/produtoseservicos/ analisedosolo/docs/Boletim_Tecnico_106_rev_atual_2009.pdf. Acesso em: 20 jun. 2019.

CARVAlho, C. C. N. de; NUNES, F. C.; ANTUNES, M. A. H. Histórico do levantamento de solos no Brasil: da industrialização brasileira à era da informação. Revista Brasileira de Cartografia, v. 65, n. 5, p. 997-1013, 2013.

CUNHA, T. J. F. et al. Principais solos do Semiárido tropical brasileiro: caracterização, potencialidades, limitações, fertilidade e manejo. In: SA, I. B.; SILVA, P. C. G.da. (ed.). Semiárido brasileiro: pesquisa, desenvolvimento e inovação. Petrolina: Embrapa Semiárido, 2010. p. 50-87.

DALMOLIN, R. S. D. et al. Relação entre as características e o uso das informações de levantamentos de solos de diferentes escalas. Ciência Rural, v. 34, n. 5, p. 1479-1486, 2004.

DOKUCHAEV, V. V. Short storical description and critical analysis of the more important soils classification. Trav. Soc. Nat. St. Petersburg, v. 10, p. 64-67, 1879.

EAKIN, H. C.; LEMOS, M. C.; NELSON, D. R. Differentiating capacities as a means to sustainable climate change adaptation. Global Environmental Change, v. 27, n. 1, p. 1-8, jul. 2014.

EMPRESA BRASILEIRA DE PESQUISA AGROPECUÁRIA. Manual de análises químicas de solos, plantas e fertilizantes. 2. ed. Brasília, DF: Embrapa Informação Tecnológica, 2009.

FRANCO, Â. M. P. et al. Delineamento das unidades de mapeamento de solos utilizando o Google Earth. Geociencias, v. 34, n. 4, p. 861-871, 2015.

GIASSON, E.; INDA JUNIOR, A. V.; NASCIMENTO, P. C.do. Estimativa do benefício econômico potencial de dois levantamentos de solos no Estado do Rio Grande do Sul. Ciência Rural, v. 36, n. 2, p. 478-486, 2006.

INTERGOVERNMENTAL PANEL ON CLIMATE CHANGE. Climate change 2014: impacts, adaptation, and vulnerability. Part A: global and sectoral aspects. In: FIELD, C. B. et al. (ed.). Contribution of working group 2 to the fifth assessment report of the intergovernmental panel on climate change. Cambridge: Cambridge University Press, 2014. p. 1132.

MARENGO, J. A. Vulnerabilidade, impactos e adaptação à mudança do clima no semi-árido do Brasil. Parcerias Estratégicas, v. 13, n. 27, p. 149-175, 2008.

MARENGO, J. A.; TORRES, R. R.; ALVES, L. M. Drought in Northeast Brazil: past, present, and future. Theoretical and Applied Climatology, v. 129, n. 3-4, p. 1189-1200, 2016.

MENDONÇA, E. de S.; MATOS, E. da S. Matéria orgânica do solo: métodos de análises. Viçosa, MG: UFV, 2005.

OLIVEIRA, J. B. Pedologia aplicada. 4. ed. Piracicaba: FEALQ, 2011.

RAIJ, B. VAN et al. Análise química para avaliação da fertilidade de solos tropicais. Campinas: Instituto Agronômico de Campinas, 2001.

SANTOS, H. G. et al. Procedimentos normativos de levantamentos pedológicos. Rio de Janeiro: Embrapa - Serviço de Produção de Informação, 1995.

SANTOS, H. G. et al. Sistema brasileiro de classificação de solos. 5. ed. Brasília, DF: Embrapa Solos, 2018.

TEN CATEN, A. et al. Mapeamento digital de classes de solos: características da abordagem brasileira. Ciência Rural, v. 42, n. 11, p. 1989-1997, 2012. 